\title{
NMDA Receptors in the Developing Brain and Effects of Noxious Insults
}

\author{
Karen A. Waters ${ }^{a-c}$ Rita Machaalani ${ }^{a}$ \\ Departments of a Medicine and ${ }^{b}$ Paediatrics and Child Health, The University of Sydney, and \\ 'The Children's Hospital at Westmead, Sydney, N.S.W., Australia
}

\section{Key Words}

Animal models · Brain · Hypercapnia $\cdot$ Hypoxia $\cdot$ Infant brain $\cdot$ Ischemia $\cdot$ Nicotine $\cdot$ Sudden infant death syndrome

\begin{abstract}
This review covers normal expression of the NMDA receptor in the fetus and newborn, and then the response of the NMDA receptors within the central nervous system (CNS) during early development, to noxious stimuli. In the research setting, hypoxia is a commonly studied noxious stimulus that has been studied in a variety of contexts, including isolated hypoxia, or hypoxia combined with ischemia or hypercapnia, and delivered in single or repeated doses (intermittent stimuli). We review differences and commonalities between these experimental paradigms, and the sequelae of a common outcome, which is cell death, possibly through excitotoxic mechanisms. Finally, based on current literature, we will examine potential directions for clinical therapeutic interventions. By highlighting knowledge gaps in this field, we hope to encourage future research focusing on clinically relevant problems and outcomes in this area.
\end{abstract}

Copyright $(2004$ S. Karger AG, Basel

\section{Introduction}

Cellular functions within the brain are critically dependent on matching the rate of oxygen delivery with that of oxygen consumption, so that oxygen deprivation, whether acute or chronic, constitutes a noxious stimulus. Most protocols of limiting brain oxygen supply are designed to mimic specific clinical scenarios, although their unifying characteristic is cellular energy depletion causing loss of function of cellular adenosine tri-phosphate (ATP). Differences between the insults affects the rapidity of onset, the timing and adequacy of the re-oxygenation (energy restoration), and/or the clearance of other toxic cellular metabolites. Different studies also address different outcome measures, and may or may not include the study of neuroprotective strategies. Most commonly, the sequelae of these events are studied after a single insult, so this will be the primary focus of our review. Many clinical stimuli are intermittent, and the process of re-oxygenation may contribute to the detrimental effects of such a stimulus, so some recent experimental paradigms include examination of the sequelae of second and subsequent exposures to cyclical or repeated stimuli, where the likelihood of neuronal degeneration, neurological damage and/or death may be increased [1]. Although studies have looked at many diverse sequelae of such insults, the focus of this

\begin{tabular}{ll}
\hline KARGER & @ 2004 S. Karger AG, Basel \\
Fax +4161306 1234 $34-862 X / 04 / 0134-0162 \$ 21.00 / 0$ \\
$\begin{array}{l}\text { E-Mail karger@karger.ch } \\
\text { www.karger.com }\end{array}$ & $\begin{array}{l}\text { Accessible online at: } \\
\text { www.karger.com/nsg }\end{array}$
\end{tabular}

Dr. Karen A. Waters

Department of Medicine, Room 206, Blackburn Building, DO6

University of Sydney

Sydney, NSW 2006 (Australia)

Tel. +61 29351 5165, Fax +6129550 3851, E-Mail kaw@med.usyd.edu.au 
review is how these insults affect the N-methyl- $D$-aspartate (NMDA) neurotransmitter system within the developing (immature) brain.

A body of evidence exists to support the contention that noxious insults such as hypoxia and ischemia induce changes in NMDA receptor expression and function in the developing brain [2-5]. This evidence includes fetal and neonatal insults, and is largely derived from animal models of brain injury during the perinatal period. The major role of the NMDA system in response to noxious insults is in excitotoxicity, which is a form of active cell death occurring as the result of excessive and abnormal activation by glutamate of NMDA receptors [6].

Our focus in this review is on changes pertaining to the NMDA receptor in the developing brain after exposure to noxious stimuli that include hypoxia (hypoxia, hypercapnic-hypoxia $(\mathrm{HH})$, or hypoxic-ischemia (HI)), or nicotine because of the relevance of the nicotinic receptor system to ventilatory and therefore hypoxic responses, as well as its purported role in the sudden infant death syndrome (SIDS), an area of research of particular interest in our laboratory.

\section{The Developing Brain}

In the perinatal period, the human fetus undergoes a critical period of brain development. This period corresponds to $6-10$ postnatal days for rats and 2 weeks before to 4 weeks after birth in piglets. This critical period is defined by the peak rate of brain growth [7], enhanced synaptogenesis [8], and the developmental regulation of receptor populations [9]. One well-studied receptor population includes the glutamatergic ionotropic receptors: NMDA, $\alpha$-amino-3-hydroxy-5-methyl-4-isoxazole-4-propionate (AMPA) and kainite $[9,10]$. In the human brain, NMDA receptor activity and expression increase in the infant period, whereas AMPA and kainate receptors are elevated during mid-gestation and decrease thereafter [9]. Thus, the newborn infant brain is more susceptible to NMDA- than AMPA- or kainate-mediated injury.

This critical period of brain development is also characterized by a high rate of regulated neuronal cell death, via apoptotic mechanisms $[11,12]$. This cell death affects particular brain regions during specific developmental phases, and occurs in the brainstem during the perinatal period [13], thalamus and other subcortical areas soon after birth $[14,15]$ and cortical areas in the first 2 postnatal weeks $[15,16]$. Moreover, this cell death seems to be specifically regulated by caspase- 3 , a cysteine protease
Table 1. Brain regions selectively vulnerable to noxious insults

\begin{tabular}{ll}
\hline Noxious insult & Brain regions predominantly affected \\
\hline $\begin{array}{l}\text { Hypoxia } \\
\text { Hypoxic-ischemia }\end{array}$ & $\begin{array}{l}\text { Brainstem, hippocampus, cortical regions } \\
\text { Cerebral cortex (white matter), thalamus, } \\
\text { putamen, basal ganglia } \\
\text { Bypercapnic-hypoxic }\end{array}$ \\
\hline
\end{tabular}

enzyme that initiates the apoptotic cascade, since caspase3 mRNA is abundantly expressed in the fetal and infant cerebral cortex compared to the adult [17].

\section{Noxious Insults to the Developing Brain}

The clinical results of cerebral insults to the fetus or infant may be focal or global, and include mental retardation, cerebral palsy, seizures, deafness and blindness, although for many, the timing and characteristics of the insult remains unknown $[18,19]$. Vulnerability of the brain to NMDA-mediated injury shows regional (table 1) and age-related differences that could result in different patterns of neurodegeneration and neurobehavioral disturbance. Age-specific patterns of vulnerability can be observed in the neonatal brain after near-total asphyxia, and vulnerabilities of particular regions are thought to be due to their shared excitatory connections and the fact that they use glutamate as their neurotransmitter [20,21]. In the neonatal human, HI predominantly affects systems that control tone and movement [22], and magnetic resonance imaging (MRI) has revealed selective injury to the sensorimotor cortex, basal ganglia, thalamus and putamen following severe birth asphyxia in full-term infants [23].

Experimental paradigms of noxious insults that affect the developing brain can be classified as follows:

1. Hypoxia - lower than normal oxygen content in the lungs, blood or tissue. Hypoxemia refers to low oxygen content in arterial blood; thus, tissue can be hypoxic even though there is no hypoxemia. Hypoxia is usually achieved by reducing inspired oxygen concentrations, but hypoxic-hypoxia is achieved by administration of carbon monoxide. In animal studies, it has been shown that compensatory cerebral autoregulation increases cerebral blood flow (CBF) and protects the brain tissue from a major fall in oxygen availability [24]. Where CBF is still close to normal, glucose supply to the brain is maintained. 
2. Ischemia - markedly reduced or absent circulation. The two common experimental paradigms are: (a) global ischemia, where there is a reduction of arterial blood flow to the brain caused by cardiac arrest, shock, carotid occlusion or hypotension, and (b) focal ischemia, with reduced blood flow confined to the brain, or brain regions of interest. These model the clinical situations of seizures and/or cerebrovascular accidents. In severe ischemia (with tissue hypoxia), energy production is deficient due to the insufficient delivery of oxygen to brain cells, and it is associated with a fall in glucose levels and metabolic acidosis. These factors combine to cause exhaustion of cellular oxygen stores within $30 \mathrm{~s}$, and of glucose and ATP stores within 5 min of onset [25].

3. Hypoxic-ischemia (HI) - In clinical situations, severe hypoxia is often complicated by other physiological insults that counteract the homeostatic effect of cerebral vasodilation, including hypotension. This is mimicked in animals by combining vascular occlusion with hypoxia. With reduced circulation and hypoxia combined, cellular exposure includes hypoxia, hypercapnia (respiratory acidosis), hypoglycemia, and metabolic acidosis [26]. Clinical examples include cardiorespiratory failure, and perinatal asphyxia with bradycardia.

4. Asphyxia - for the purpose of this review, asphyxia is used to refer to the combination of hypercapnia and hypoxia. Whole animal exposure likely results in some accumulation of toxic metabolic products. Clinically, such asphyxial insults include sleep-related breathing disorders (e.g., obstructive sleep apnea), facial entrapment, or respiratory failure secondary to lung or neuromuscular disease. The cellular defects resulting from this insult are dependent upon the presence of hypoxia, since even at very high levels of hypercapnia without hypoxia (arterial carbon dioxide tension $\left(\mathrm{PCO}_{2}\right)$ of $90 \mathrm{~mm} \mathrm{Hg}$, with brain $\mathrm{pH}<6.90)$ changed energy state or gross or irreversible brain injury are not seen [27-29]. The presence of hypercapnia in the absence of circulatory compromise is likely to exacerbate hypoxia-related injury as in studies where maintenance of other substrates (e.g., glucose) exacerbates lactic acidosis and subsequent injury [26]. Asphyxia in this setting is distinct from definitions of neonatal asphyxia, which is really hypoxia-ischemia. In neonatal asphyxia, oxygen and substrate delivery are both compromised and levels of metabolic (lactic) acidosis are used to define the severity of the condition [30].

5. Substances of abuse - systemic, or cellular exposure to toxins. The most commonly studied substances of abuse are ethanol (in relation to fetal alcohol syndrome [reviewed in 31,32]), nicotine, and opioids. Their effects during pregnancy appear to include fetal hypoxia by depleting hemoglobin oxygen stores available to the fetus [33], although most clinical examples include mixed, and/ or multiple exposures to these substances.

\section{NMDA Receptors}

NMDA receptors are heteromeric complexes comprising of an NR1 subunit combined with one or more NR2 or NR3 subunits. There are at least 8 splice variants of the NR1 subunit (NR1A-NR1H) [34], 4 genetically different NR2 subunits (NR2A-NR2D) [35, 36] and to date, 2 genetically different NR3 subunits (NR3A, NR3B) [37]. Although the NR1 subunit is an obligatory component of functional NMDA receptors, the NR2 subunits determine the biophysical and pharmacological activity of the receptor. Thus, the NR2 subunits determine the singlechannel conductance and kinetic properties, the time course of current deactivation, and the affinity and sensitivity for agonists and antagonists such as glutamate, glycine and magnesium $\left(\mathrm{Mg}^{2+}\right)$ [38]. The NR1 subunit is widely expressed throughout the CNS at all ages, but the expression profiles of the NR2 subunits in the brain are developmentally and regionally regulated [35]. For example, in the rat, NR2B and NR2D subunits predominate in the neonatal brain, but as development proceeds, they are supplemented with, or replaced by the NR2A and NR2C subunits in some brain regions [36, 39]. Furthermore, NR2A mRNA expression predominates in the cerebral cortex and hippocampus, while NR2B predominates in the forebrain, NR2C in the cerebellum and diencephalon and NR2D in the lower brainstem regions [35, 36, 40].

Activation of the NMDA receptor is regulated by several distinct pharmacological binding sites, which include the following: (1) neurotransmitter binding site or recognition site that binds glutamate or NMDA, (2) co-activator site that binds glycine, (3) channel site that binds MK801 in its open state, (4) voltage-dependent $\mathrm{Mg}^{2+}$ site, (5) polyamine site that binds spermine and spermidine, (6) ifenprodil site, and (7) inhibitory divalent cation site that binds $\mathrm{Zn}^{2+}[41]$.

The NMDA receptor also has a cation-selective ion channel that gates $\mathrm{Na}^{+}, \mathrm{K}^{+}$and $\mathrm{Ca}^{2+}$ ions. This channel is regulated by $\mathrm{Mg}^{2+}$, which serves to block $\mathrm{Ca}^{2+}$ influx in a voltage-dependent manner [42].

The influx of $\mathrm{Ca}^{2+}$ appears to be the initiating step for biochemical processes responsible for both NMDA receptor-induced synaptic plasticity in the developing brain [43] and NMDA receptor-mediated excitotoxicity [44]. 


\section{NMDA Receptors in the Developing versus Adult Brain}

Several characteristics of the NMDA neurotransmitter system make the NMDA regions of the immature brain particularly vulnerable to NMDA-mediated excitotoxicity after hypoxic insults [45]. First, during early development, brain NMDA receptor content and activity is high. Second, the functions of the NMDA system are important in the maturation and plasticity of developing neurons. Finally, changes in NMDA receptor configuration and affinity for its transmitters after exposure to noxious stimuli increase the risks for specific 'NMDA-mediated' sequelae (particularly excitotoxicity).

In the developing brain, NMDA receptor activity is high compared to the adult brain [46-48]. Main features of NMDA receptor activity specific to the developing brain as compared to the adult include: lower sensitivity to the channel block by $\mathrm{Mg}^{2+}$, higher sensitivity to glycine, differential modulation by polyamines, increased calcium influx through the receptor channel, longer duration of the excitatory postsynaptic potentials (EPSPs) after receptor stimulation, and enhanced ability to induce markers of synaptic plasticity such as long-term potentiation (LTP) [49-51]. All these differences have led to the proposal that the role of the NMDA receptor in regulating brain development is through activity-dependent rather than experience-dependent mechanisms [52, 53].

Receptor-binding studies and immunohistochemical localization of the subunits indicate that the expression and number of NMDA receptors are also greater in the developing than the mature brain. In the human brainstem, NMDA receptors are not expressed during the fetal period but increase to a peak during the infant period and decrease thereafter [9], with similar patterns observed in the human frontal [54], temporal [55], and prefrontal [10] cortex.

\section{Role of the NMDA Receptor}

\section{Under Normal Conditions}

NMDA receptors have a direct role in neuronal proliferation [56, 57], migration [58-60], synaptic plasticity [52, 61-63], and injury. The role of NMDA receptors in excitotoxicity and synaptic plasticity in the developing brain has been reviewed in detail elsewhere [61]. Functionally, NMDA receptors are highly expressed in brain regions that control respiration $[64,65]$, feeding and relat- ed physiological functions [66-68], learning and memory $[66,67,69]$, and pain perception [70].

The role of the NMDA receptor in neuronal proliferation (neurogenesis) was determined pharmacologically in some brain regions. Blocking NMDA receptors with daily injections of the antagonist MK-801 for 3 days in the 2day-old rat resulted in a significant increase of cell birth in the dentate gyrus [56, 57], while activation of NMDA receptors resulted in decreased proliferation of the granule cells of the dentate gyrus [71].

Recent studies have identified a role for the NMDA receptor in neuronal migration. Migration (maturation) of postmitotic neurons from where they were generated to their final destination, before differentiation and synaptogenesis, is a central event in brain development $[59,60]$. Migrating cortical neurons possess functional NMDA receptors before they undergo synaptogenesis [72], and pharmacological studies have shown that blocking of NMDA receptors in cerebellar slices, or increasing magnesium concentrations in the medium, slows the rate of granule cell migration. Confirming that NMDA is integral to this process, the rate of migration was increased if magnesium was removed, glutamate increased, or exogenous glycine was added to the medium [58]. Patch clamp studies show that the migrating granular cells have higher functional NMDA receptor content compared to premigratory neurons [73]. Similarly, in cortical slices from the rat and mouse, NMDA receptor activation stimulates neuronal migration $[74,75]$.

Synaptic plasticity (synaptogenesis) is the key factor in shaping the wiring pattern of the brain, and is responsible for the mechanism of learning and memory $[62,63,76]$. Direct injections of NMDA into the occipital cortex of 8-day-old rats (age at which there is a peak vulnerability to both NMDA injections and HI [61]) resulted in an increase in synaptic density (number of synapses) [62]. Conversely, NMDA receptor blockade resulted in a decrease in the total number of synapses [63], and was associated with deficits in learning and memory [77], thus confirming an important role of the NMDA receptor in synaptogenesis. Currently, the two most studied examples of synaptic plasticity are LTP (a long-lasting increase of synaptic efficacy consequent to a short stimulation with high frequency bursts [78]) and long-term depression (LTD; the opposite of LTP and refers to a long-lasting decrease of synaptic efficacy following a high frequency stimulation [79]). 
Fig. 1. Hypothesized time sequence of events after a single or continuous noxious insult (assuming translational processes are still normal). Immediately after the insult, changes in NMDA receptor mRNA occur and translate into protein changes. The formation of functional NMDA receptors is disrupted within hours and translates into an alteration of the NMDA receptor activity (usually increased) that could last for days. Excitotoxic mechanisms are induced and result in cell death and loss that is experimentally visible within hours to days. The ultimate consequence of the noxious insult is physiological compromise and/or death (weeks to years).

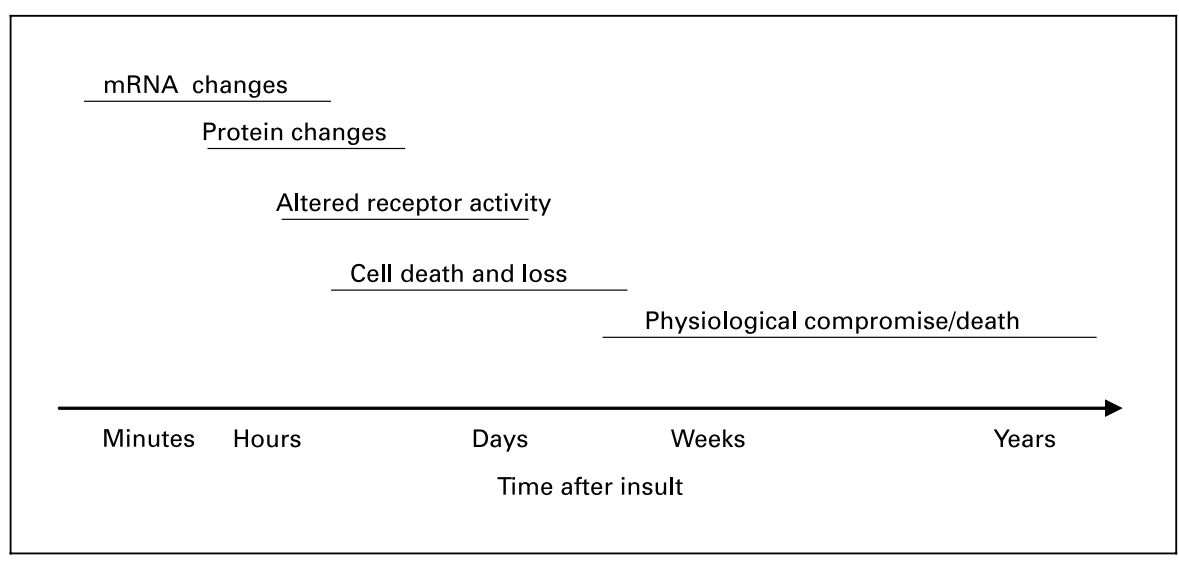

\section{Under Pathological Conditions}

Much attention has been paid to changes in the NMDA receptor under noxious conditions since the identification of the process known as 'excitotoxicity', an excessive and abnormal activation of glutamate receptors leading to cell death [6]. While this process is not specific to the NMDA-glutamatergic system, the NMDA receptor is the predominant excitatory neurotransmitter system involved in this process. The final outcomes of hypoxia induced and NMDA-mediated brain injury may take a few hours and days to present (fig. 1) and are often determined by the events that arise during the period following the insult. For example, brain injury in infants who suffer from birth asphyxia, is associated with a period of encephalopathy with seizures, reduced level of consciousness and poor feeding within hours and days of the insult [80-82].

\section{Cell Death}

During and/or after hypoxic exposures, a cascade of events is triggered (schematically represented in fig. 2) including an increase in extracellular glutamate that results in the overactivation of the NMDA receptors, and calcium entry into cells causing increased intracellular $\mathrm{Ca}^{2+}$, and activation of proteins (e.g., caspase-3) that lead to cell death (apoptosis or necrosis).

Whether the resulting cell death is apoptotic or necrotic in type depends on the duration and intensity of the initiating insult and the age of the neuron. In vitro and in vivo studies in the CNS suggest that a mild excitotoxic insult leads to transient mitochondrial depolarization and reversible energy compromise with cellular apoptosis. More intense injuries produce irreversible mitochondrial depolarization and permanent energy collapse with cellular necrosis $[44,83]$. There are also age-associated in-

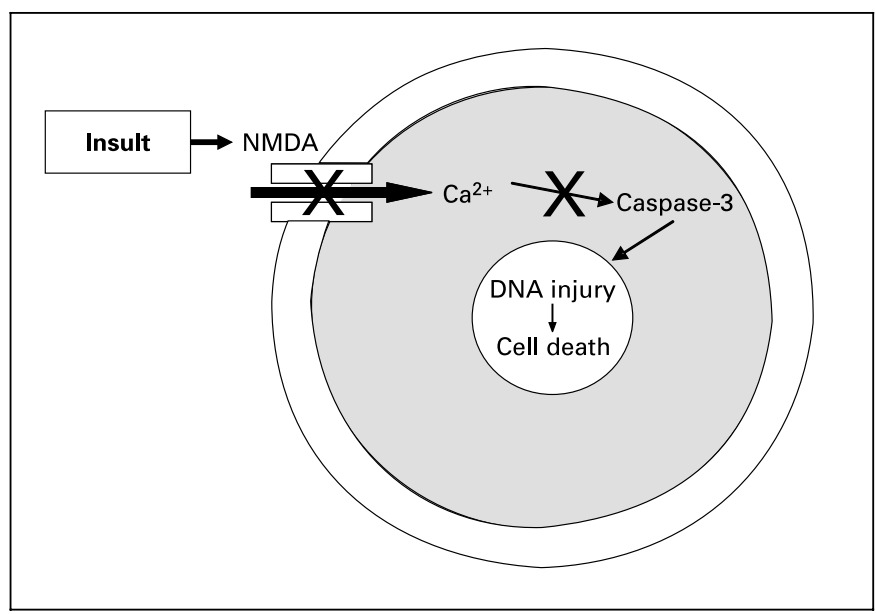

Fig. 2. Schematic representation of the major events triggered in a neuron after hypoxic insults. The noxious insult activates the NMDA receptors located in the external membrane of certain neurons. As the insult progresses, the receptors become overstimulated (excitotoxic) causing an excessive influx of calcium through the cation selective ion channel. Increased intracellular calcium activates a number of enzymes (proteases) in the cytoplasm, of particular note caspase- 3 which is an initiator of the caspase cascade, with the final result being cleavage, degradation and/or fragmentation of chromosomal DNA and thus, death of the neuron. Crosses indicate possible sites of therapeutic intervention to prevent NMDA-mediated cell death after noxious insults.

fluences on these processes, since apoptotic death predominates amongst immature neurons whilst necrotic death predominates amongst mature neurons. Although these are usually represented as completely distinct phenomena, recent studies suggest that some cells undergo a hybrid form of cell death with features of both apoptosis and necrosis [84]. In addition, the cell death process is transient, commencing approximately $30 \mathrm{~min}$ after NMDA 
Table 2. Animal models of hypoxic, asphyxic (hypercapnic-hypoxic) and hypoxic-ischemic (HI) brain injury

\begin{tabular}{|c|c|c|c|c|}
\hline \multirow[t]{2}{*}{ Insult } & \multicolumn{2}{|l|}{ Prenatal } & \multicolumn{2}{|l|}{ Postnatal } \\
\hline & reference & characteristics & reference & characteristics \\
\hline Hypoxic & 92,93 & $\begin{array}{l}\text { Inspired hypoxia } \\
\text { Duration: } 60 \mathrm{~min} \\
\text { Animal: guinea pig } \\
\text { Confirmation: } \downarrow \text { ATP and } \operatorname{PCr}(\sim 90 \%)\end{array}$ & $2,95-99$ & $\begin{array}{l}\text { Inspired hypoxia }\left(\mathrm{FiO}_{2}=0.07-0.15\right) \\
\text { (anesthesia and mechanical ventilation) } \\
\text { Duration: } 20-60 \mathrm{~min} \\
\text { Animal: newborn piglet, } 2-4 \text { days old } \\
\text { Confirmation: } \mathrm{PaO}_{2} \text { on average }<25 \mathrm{~mm} \mathrm{Hg} \text {, } \\
\downarrow \text { ATP }(\sim 50 \%) \text { and } \mathrm{PCr}(\sim 80 \%) \\
\text { Hypoxic chamber }\left(6.5 \% \mathrm{O}_{2}\right) \\
\text { Duration: } 70 \text { min } \\
\text { Animal: infant rat, } 4 \text { days old } \\
\text { Confirmation: no data }\end{array}$ \\
\hline Asphyxic & & & 5,100 & $\begin{array}{l}\text { Inspired hypercapnia }\left(7 \% \mathrm{CO}_{2}\right) \text { and } \\
\text { hypoxia }\left(8 \% \mathrm{O}_{2}\right)(\mathrm{HH}) \\
\text { Duration: intermittent for total } 24 \mathrm{~min} \text { of } \mathrm{HH} \\
\text { Animal: infant piglet, } 9-12 \text { days old } \\
\text { Confirmation: } \mathrm{PaO}_{2} 40.9 \pm 1.9 \mathrm{~mm} \mathrm{Hg} \\
\text { and } \mathrm{PaCO}_{2} 61.2 \pm 4.2 \mathrm{~mm} \mathrm{Hg}\end{array}$ \\
\hline Hypoxic-ischemia & 101 & $\begin{array}{l}\text { Uterine vessel clamp } \\
\text { Duration: } 30 \text { min with reperfusion } \\
\text { Animal: rat pups studied on postnatal } \\
\text { days } 1,4,8 \text { and } 30 \\
\text { Confirmation: no data }\end{array}$ & 102 & $\begin{array}{l}\text { Unilateral carotid artery ligation and } \\
\text { hypoxia }\left(8 \% \mathrm{O}_{2}\right) \\
\text { Duration: } 90-120 \text { min } \\
\text { Animal: infant and adult rat ( } 7 \text { and } 21 \text { days) } \\
\text { Confirmation: no data } \\
\text { Hypoxia (mechanically ventilated; } \\
\text { FiO }=0.1) \text { then airway occlusion } \\
\text { Duration: } 30 \text { and } 70 \text { min } \\
\text { Animal: newborn piglet, } 7 \text { days old } \\
\text { Confirmation: hypoxia } \mathrm{SaO}_{2}(30 \%) \\
\text { Ischemia } \mathrm{SaO}_{2}(5 \%)\end{array}$ \\
\hline
\end{tabular}

'Confirmation' = Confirmation of tissue hypoxia. ATP = Adenosine tri-phosphate; $\mathrm{FiO}_{2}=$ fractional inspired oxygen concentration; $\mathrm{mm} \mathrm{Hg}=$ millimeters of mercury; $\mathrm{PaO}_{2}=$ arterial oxygen tension; $\mathrm{PaCO}_{2}=$ arterial carbon dioxide tension; $\mathrm{PCr}=$ phosphocreatinine; $\mathrm{SaO}_{2}=$ arterial oxygen saturation.

receptor overstimulation and depending on the severity of the insult and brain regions studied, it can be observed as soon as $1 \mathrm{~h}$ after the insult and for days thereafter (fig. 1).

In young developing piglets, it has been found that cell death tends to occur in brain regions with a high basal NR 1 expression in the brainstem after hypercapnic-hypoxia (HH) [85], and in the caudate and putamen after HI [86].

\section{Animal Models Used to Study Changes in NMDA Receptors}

The majority of studies that focus on delineating the mechanisms of brain damage induced in the human infant by noxious insults are undertaken in isolated cellu- lar preparations, or in animal models. Various animal models of hypoxic, asphyxic, and hypoxic-ischemic (HI) brain injury have been developed and used for the study of the NMDA system. Those of relevance to this review are summarized in table 2 .

Experimental techniques commonly employed to study the expression of NMDA receptors focus on the localization and distribution of subunit mRNAs and/or proteins, and include immunohistochemistry, in-situ hybridization, polymerase chain reaction, or receptor binding. Expression of NMDA subunits, or function of the NMDA receptors, varies in response to noxious stimuli (increase, decrease or no change), but these differences may be explained by the fact that subunit expression does not always guarantee the presence of functional NMDA 
Table 3. Changes in NMDA subunit expression after noxious insults during development

\begin{tabular}{ll}
\hline Evidence & References \\
\hline$N R 1$ & \\
$\uparrow$ in 3 brainstem nuclei (mRNA; HH), caudate and putamen (protein; HI) & 5,86 \\
$\downarrow$ in 1 brainstem nucleus (protein; HH), cortex and hippocampus (mRNA; HI) & 5,101 \\
No change in 9 brain regions (protein; hypoxia) and forebrain (protein; HI) & 91,102 \\
\hline$N R 2 A$ & 104 \\
$\uparrow$ in cortex (mRNA; nicotine) & 102 \\
$\downarrow$ (delayed) in forebrain (protein; HI) & $86,91,101$ \\
\hline No change in 9 brain regions (protein; hypoxia), in cortex, hippocampus, caudate and & 86 \\
$\quad$ putamen (protein; HI) & 102,104 \\
\hline$N R 2 B$ & 91,101 \\
$\uparrow$ in caudate and putamen (protein; HI) & \\
$\downarrow$ in forebrain (protein; HI), thalamus (mRNA; nicotine) & 101 \\
No change in 9 brain regions (protein; hypoxia), cortex and hippocampus (protein; HI) & \\
\hline$N R 2 C$ and $N R 2 D$ & \\
No change in cortex and hippocampus (protein; HI) & \\
\hline \multicolumn{2}{l}{$H \mathrm{H}$ = Hypercapnic-hypoxia; HI = hypoxic-ischemia. Refer to table 2 for details of exposure and animal model. } \\
\hline
\end{tabular}

Table 4. Changes in NMDA receptor function after noxious insults during development

\begin{tabular}{ll}
\hline Evidence & References \\
\hline $\begin{array}{l}\text { Binding affinity for } M K \text {-801 } \\
\text { in cerebral cortex (hypoxia) }\end{array}$ & 2 \\
$\downarrow$ in hypothalamus, amygdaloid nuclei, cortex (hypoxia), and hippocampus (hypoxia, HI) & 2,101 \\
\hline Binding affinity for glutamate, $M g^{2+}, C P P$ & $2,94-96$ \\
$\uparrow$ in cerebral cortex (hypoxia) & $92,96,98$ \\
\hline Number of NMDA receptors & 101 \\
$\downarrow$ in cerebral cortex (hypoxia) & \\
Not changed in hippocampus (HI) & 93 \\
\hline $\begin{array}{l}\text { Activation of NMDA receptors } \\
\text { in spermine-dependent activation in the cortex (hypoxia) } \\
\downarrow \text { in glutamate- and glycine-dependent activation in the cortex (hypoxia) }\end{array}$ & 93 \\
\hline $\begin{array}{l}\text { Phosphorylation and nitration of subunits } \\
\uparrow \text { phosphorylation of NR1 in caudate and putamen, and of NR2B in forebrain (HI) }\end{array}$ & 86,102 \\
$\uparrow$ nitration of NR1, NR2A and NR2B in cerebral cortex (hypoxia) & 99 \\
\hline \multicolumn{2}{l}{ HH = Hypercapnic-hypoxia; HI = hypoxic-ischemia. Refer to table 2 for details of exposure and animal model. } \\
\hline
\end{tabular}

receptors, so a change in expression cannot be taken to infer a change in function. Nonetheless, changes in expression after a noxious insult provide information regarding alterations in activity and disturbances in regulatory processes (translational regulation), particularly when mRNA and protein are studied simultaneously. Expressional changes of the NMDA receptor after noxious insults during development are reviewed below and summarized in table 3 . 
Experimental techniques for studying receptor function include receptor binding, receptor blockade, and receptor activation. Binding characteristics include the number of receptors $\left(B_{\max }\right)$ and the binding affinity of the receptors $\left(\mathrm{K}_{\mathrm{d}}\right)$. The phosphorylation state of receptor proteins also provides information of receptor function since functional activity of the NMDA receptor is regulated by phosphorylation [87-90]. Functional changes of the NMDA receptor after noxious insults are reviewed below and summarized in table 4.

\section{Hypoxia}

Studies to date have predominantly investigated functional changes in the NMDA receptor, and no changes have been found in receptor expression, after hypoxia. However, NMDA receptor function is clearly affected by hypoxia. In the newborn, hypoxia induces a reduction in the total number of NMDA receptors, but more variable changes in receptor binding. The regional and age-dependent variability in receptor binding can be explained by differences in the response of the NMDA receptor subunits. Some findings can be explained by either increased NMDA ion-channel-binding sites, or decreased numbers of NMDA receptors.

Expression: In the newborn piglet model of postnatal hypoxia, $1 \mathrm{~h}$ of hypoxia has no effect on NR1, NR2A and NR2B protein levels in nine brain regions, including the frontal, parietal and temporal cortices, thalamus, hypothalamus, hippocampus, white matter, basal ganglia and cerebellum [91].

Function: Prenatal hypoxia resulted in a decrease in the number of NMDA receptors [90], decreased glutamate- and glycine-dependent activation of the NMDA receptor, and increased spermine-dependent receptor activation [93]. Postnatal hypoxia increases NMDA receptor affinity for the antagonist MK-801 in the piglet cortex [2], but decreases it in several brain regions of the infant rat, including the hypothalamus, amygdaloid nuclei, entorhinal cortex, perirhinal cortex and hippocampus [3]. Postnatal hypoxia also induced an increased affinity for glutamate [2], $\mathrm{Mg}^{2+}[94,95]$, and for the antagonist, CPP (3-(2-carboxypiperazin-4-yl)propyl-1-phosphonic acid) $[96,97]$, and reduced the numbers of glutamate $[96,98]$ and CPP-binding sites $[96,97]$. Subunit-specific increases in nitration of the NR1, NR2A and NR2B have also been reported [99].

\section{Hypercapnic-Hypoxia: Asphyxia}

Expression: Intermittent exposure to hypercapnic-hypoxia $(\mathrm{HH})$ induces changes in NR1 mRNA, and protein.
In infant piglets, NR1 mRNA and protein are widely distributed in the brainstem at the level of the medulla and staining was localized to the cytoplasm (both mRNA and protein) and nucleus (mRNA only) (fig. 3, 4) [5]. Exposure to intermittent $\mathrm{HH}$ induced an increase in NR1 mRNA in three nuclei of the medulla, associated with a decrease in NR1 protein in one of the same three nuclei. The affected nuclei have functional roles in cardiorespiratory control, and in the same animal model we have documented alterations in ventilatory responses [100], so we postulate that the NMDA receptor changes are linked to the functional compromise.

\section{Hypoxic-Ischemia (HI)}

Expression: Intrauterine $\mathrm{HI}$ induces sustained effects on NR1 mRNA levels during infancy. After intrauterine $\mathrm{HI}$ in rats, mRNA for NR1 was decreased in the cortex at 1 day, and in the hippocampus at 4, 8 , and 30 days of age [101]. NR1 protein was also decreased in the hippocampus, with no changes in the NR2A-D subunit.

Postnatal HI induced an increase in NR1 protein in the caudate and putamen in the newborn piglet as well as increased NR2B expression, with no change in NR2A [86]. In the infant rat, immediately following an $\mathrm{HI}$ insult, NR2B decreased in the forebrain while tyrosine phosphorylation of NR2B increased. After 1-24 h recovery, NR2A decreased, whereas NR1 was unchanged (immediately and after recovery) [102].

Function: After intrauterine HI, binding affinity of the NMDA receptor to MK-801 was reduced in the hippocampus of infant rats, although the number of binding sites was not changed [101]. HI also increased phosphorylation of the NR1 protein in the caudate and putamen of newborn piglets [86] and of NR2B in the forebrain of the infant rat [102].

\section{Substances of Abuse - Nicotine}

Expression: Nicotine produces a selective increase in the NMDA receptor portion of the EPSP by over $100 \%$ with no change in the non-NMDA portion [103]. Only one study has examined the effects of chronic postnatal nicotine exposure on the NMDA receptor [104]. NR2A and NR2B mRNA expressions were studied in the auditory forebrain before and after nicotine exposure in 8- to 12-day-old rats. Two days of exposure produced no effects, but after 5 days, NR2A mRNA was increased in the cortex and NR2B mRNA was decreased in the thalamus [104].

NMDA Receptors after Noxious Insults 

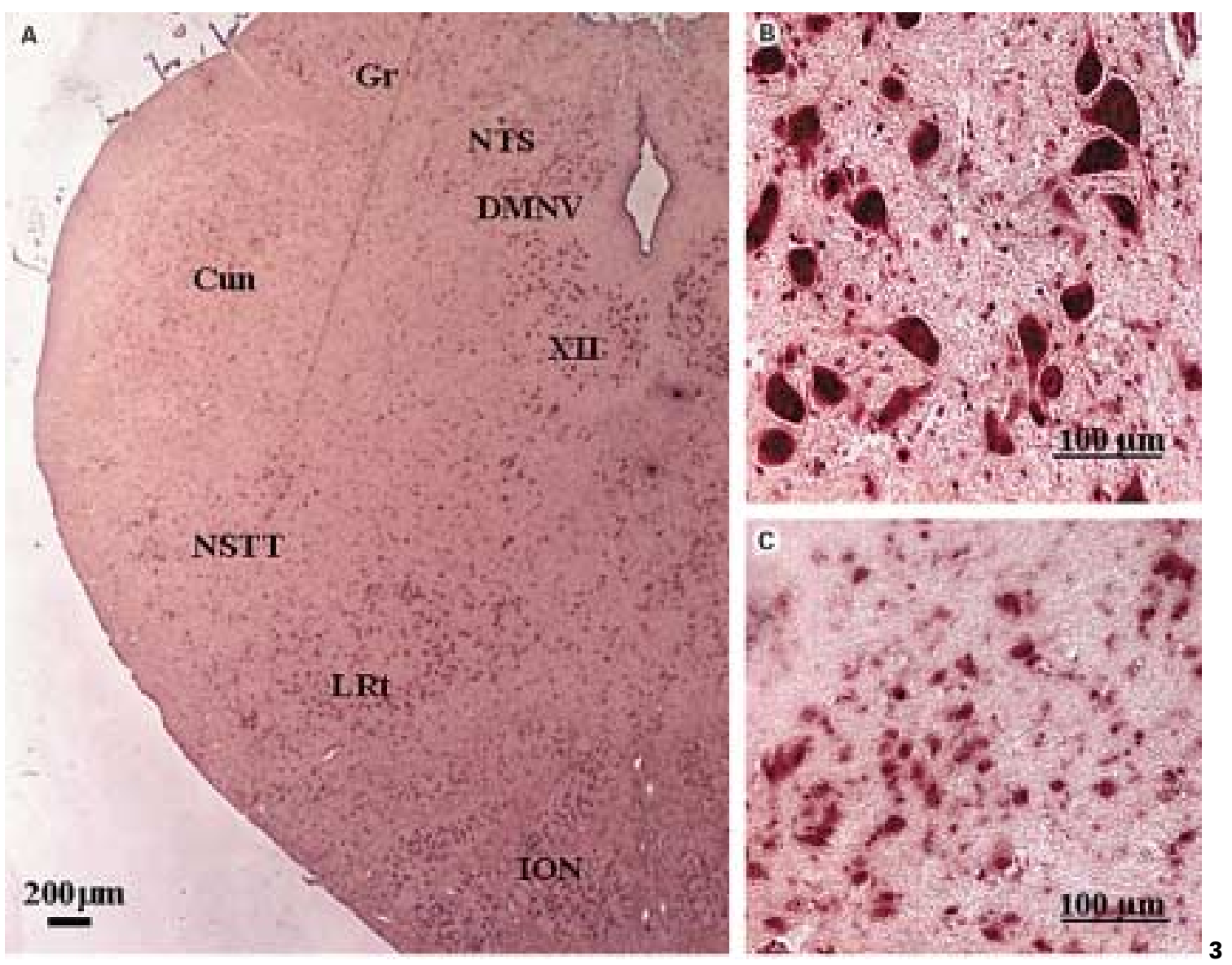

Fig. 3. NR 1 mRNA visualized by nonradioactive in situ hybridization in a normal developing piglet brainstem. (A) Transverse section of the piglet caudal medulla, (B) motor neurons of the XII nucleus, and (C) sensory neurons of the NTS. XII = Hypoglossal nucleus; $\mathrm{DMNV}=$ dorsal motor nucleus of the vagus; $\mathrm{LRt}=$ nucleus of the lateral reticular formation; ION = principle inferior olivary nucleus; NTS = nucleus of the solitary tract; $\mathrm{Gr}=$ gracile; $\mathrm{Cu}=$ cuneate; NSTT = nucleus of the spinal trigeminal tract.

Fig. 4. NR1 protein visualized by immunohistochemistry in a normal developing piglet brainstem. A Transverse section of the piglet caudal medulla, and B neurons of the ION. NR1-positive neuron (black filled arrow) and NR1-negative neuron (white filled arrowhead). See figure 3 for abbreviations.

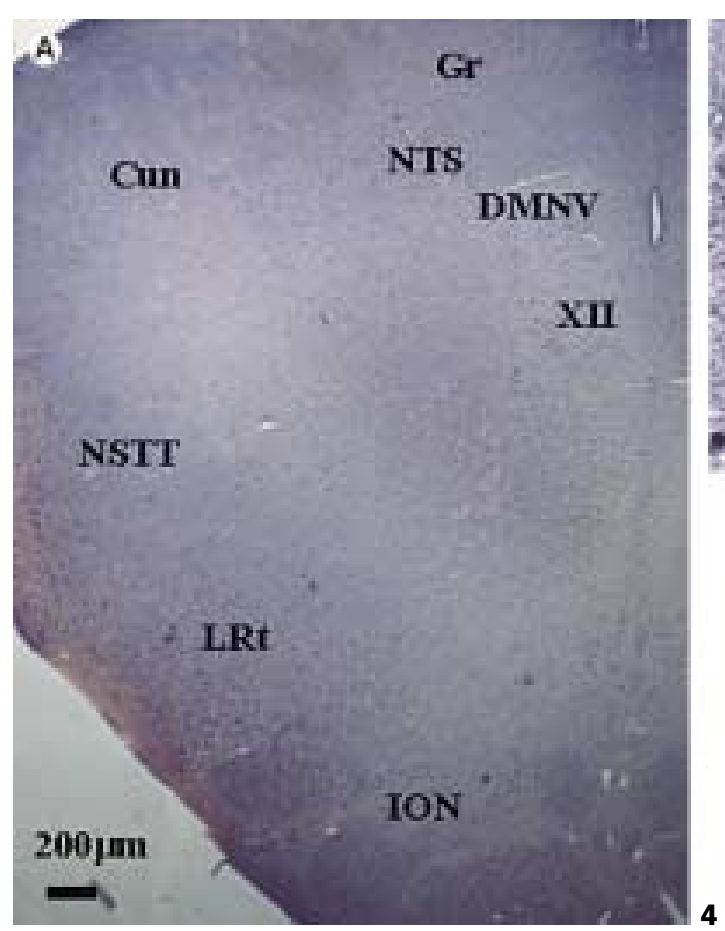

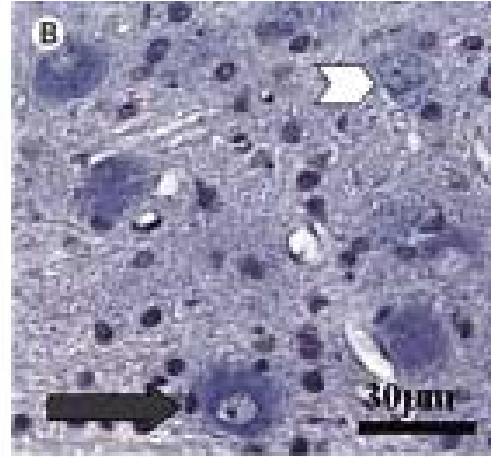

4 


\section{NMDA Receptor Changes in Human Infants}

SIDS is the leading cause of death among infants less than 1 year of age in developed countries and occurs in approximately 1-2 infants per 1,000. Victims of SIDS die suddenly during a sleep period, the cause of which remains unknown, although many hypotheses implicating hypoxic mechanisms exist [105]. The majority of infants dying in this manner have autopsies, and so brain tissue is available for study. Compared to infants dying from a known cause, infants dying from SIDS showed increased NR1 mRNA in 6 of 8 brainstem nuclei [106]. However, this increased NR1 mRNA expression only translated to increased protein expression in one of the six nuclei. These results suggest that the NMDA receptor is altered in SIDS infants, but further studies will be required to determine whether there are indications of associated functional changes in the NMDA receptor.

Acute perinatal asphyxia resulting in hypoxic-ischemic encephalopathy (HIE) occurs in approximately 2-4 per 1,000 live term newborns and leads to disabling neurological disorders in 20-30\% of affected neonates [107]. MK801 binding was studied and compared between newborn infants that had died with HIE after birth asphyxia and a control group of newborns who had died from causes unrelated to brain injury [108]. Of the four cortical regions studied (prefrontal, motor, occipital and temporal) asphyxiated infants showed an increased response to glutamate only in the temporal cortex. The severity of hypoxia did not correlate with the level of change in MK-801 binding.

\section{Therapeutic Interventions}

Regarding the responses to the noxious stimuli reviewed above, the two main options available for therapeutic intervention, and of likely potential, are NMDA receptor blockade and inhibition of caspase- 3 activation, or a combination of both [109]. NMDA receptor blockade has been extensively explored as a neuroprotective mechanism against noxious insults to the brain, but it is important to note that NMDA receptor blockade under normal conditions can exacerbate neuronal cell death [44].

Limitations exist on the use of NMDA antagonists during early development, because of their documented or potential side effects. The use of NMDA receptor blockade as therapeutic intervention, requires knowledge of the regulational factors listed above (primarily age, timing and duration of the insult, resulting damage, and brain region affected), with ongoing observation and research to determine how interactions with other neurotransmitter systems affect the response.

Clinical studies in early development are thus far limited to NMDA receptor blockade via magnesium compounds. In human neonates, $\mathrm{MgSO}_{4}$ is seen as a promising therapeutic agent, with neuroprotection greatest after 26 weeks' gestation and up to early infancy. Higher doses are required during early development than in older animals [10]. Epidemiological studies suggest that $\mathrm{MgSO}_{4}$ taken by mothers with pre-eclampsia during pregnancy reduces the incidence of cerebral palsy in low-birthweight infants [110, 111]. A clinical trial in 15 full-term infants with severe, acute asphyxial injury evaluated two doses of $\mathrm{MgSO}_{4}(250$ vs. $400 \mathrm{mg} / \mathrm{kg}$ ) and found dosedependent respiratory depression, with an unacceptable risk of hypotension at the higher dose [112]. Results in animal models have been equivocal. For example, $\mathrm{MgSO}_{4}$ in three doses $(400 \mathrm{mg} / \mathrm{kg} 1 \mathrm{~h}$ after resuscitation and $200 \mathrm{mg} / \mathrm{kg}$ at 12 and $24 \mathrm{~h}$ ) was not neuroprotective in piglets after HI, as indicated by the still present damage (apoptosis and necrosis) in the cerebral cortex [113] and the continuing cerebral energy failure [114]. In contrast, neuroprotection was observed when piglets receiving $\mathrm{MgSO}_{4}$ before and during hypoxia $(600 \mathrm{mg} / \mathrm{kg}$ over $30 \mathrm{~min}$ followed by $300 \mathrm{mg} / \mathrm{kg}$ during $60 \mathrm{~min}$ of hypoxia), whereby NMDA receptor number and affinity in the cerebral cortex was preserved [115], and the 2-fold increase in Bax:Bcl-2 ratio was prevented [116].

Animal studies have also shown that the high-affinity antagonist MK-801 has the potential for neuroprotection, but in contrast to $\mathrm{MgSO}_{4}$, it is associated with increased mortality, induces seizures, and may interfere with learning [117]. For example, MK-801 offered effective neuronal protection in rats when given within $2 \mathrm{~h}$ after the insult. Injury associated with $\mathrm{HI}$ was reduced by $53 \%$, but there was an associated 5-fold increase in mortality [118]. There is also evidence of direct toxicity from NMDA antagonists including MK-801, ketamine and CPP. Administered in the absence of any other noxious insult these agents can induce neuronal injury, with evidence of massive apoptotic neurodegeneration in several brain regions of 7-day-old rats [44]. Neurodegeneration induced by NMDA receptor blockade has also been shown to induce deficits in hippocampal synaptic function, and persistent memory/learning impairments [119]. This may have other clinically important implications, because the routine use of sedatives, anticonvulsants and anesthetics in obstetric and pediatric medicine can have the effect of NMDA receptor blockade. Pharmacological studies are therefore being directed towards newer, low-affinity 
NMDA receptor channel blockers that have wider therapeutic windows than MK-801, and clinical studies have been undertaken in adults, for example with memantine in Alzheimer's disease [120].

\section{Conclusion}

The glutamatergic system, predominantly the NMDA receptor, has important functions in the perinatal period regarding neurodevelopment. However, the characteristics of the transmitter system at this critical developmental period also mean that there is enhanced vulnerability to excitotoxic damage after exposure to noxious insults. Experimental evidence shows that hypoxia, hypoxia-ischemia, or intermittent asphyxia during early development induces expressional and functional changes in the NMDA receptor and for some, also neuronal cell death. Further evidence of the effects of re-oxygenation or re-perfusion will be required to evaluate potential therapeutic targets within these paradigms of neuronal injury. Therapeutic options are currently limited in the clinical setting because any protective effects of the NMDA antagonists are coupled with currently unacceptable risks for damage to neurodevelopmental processes.

\section{Acknowledgements}

Research funded by NH\&MRC \#980504, National SIDS Australia, The Ramaciotti Foundation, Financial Markets Trust for Children \& CHATA, NSW. Ms Rita Machaalani is a scholarship recipient from Community Health and Tuberculosis Association in Australia (CHATA). Dr. Waters is supported by an NH\&MRC Practitioner Fellowship \#206507.

\section{References}

1 Waters KA, Gozal D: Responses to hypoxia during early development. Respir Physiol Neurobiol 2003;136:115-129.

2 Hoffman DJ, McGowan JE, Marro PJ, Mishra OP, Delivoria-Papadopoulos M: Hypoxia-induced modification of the N-methyl- $D$-aspartate receptor in the brain of the newborn piglet. Neurosci Lett 1994;167:156-160.

3 Otoya RE, Seltzer AM, Donoso AO: Acute and long-lasting effects of neonatal hypoxia on (+)3-[ ${ }^{125}$ I]MK-801 binding to NMDA brain receptors. Exp Neurol 1997;148:92-99.

4 Delivoria-Papadopoulos M, Mishra OP: Mechanisms of cerebral injury in perinatal asphyxia and strategies for prevention. J Pediatr 1998; 132:S30-S34

5 Machaalani R, Waters KA: Distribution and quantification of NMDA R1 mRNA and protein in the piglet brainstem and effects of intermittent hypercapnic hypoxia. Brain Res 2002 . 951:293-300.

6 Choi DW: The role of glutamate neurotoxicity in hypoxic-ischemic neuronal death. Annu Rev Neurosci 1990;13:171-182.

7 Dobbing J, Sands J: Comparative aspects of the brain growth spurt. Early Hum Dev 1979;3: 79-83.

8 Huttenlocher PR: Synapse elimination and plasticity in developing human cerebral cortex. Am J Ment Defic 1984;88:488-496.

9 Panigrahy A, Rosenberg PA, Assmann S, Foley EC, Kinney HC: Differential expression of glutamate receptor subtypes in human brainstem sites involved in perinatal hypoxia-ischemia. $\mathbf{J}$ Comp Neurol 2000;427:196-208.

10 Chahal H, D'Souza SW, Barson AJ, Slater P Modulation by magnesium of $\mathrm{N}$-methyl- $D$-aspartate receptors in developing human brain Arch Dis Child Fetal Neonatal Ed 1998;78: F116-F120.
11 Rabinowicz T, de Courten-Myers GM, Petetot JM, Xi G, de los Reyes E: Human cortex development: Estimates of neuronal numbers indicate major loss late during gestation. J Neuropathol Exp Neurol 1996;55:320-328.

12 Dikranian K, Ishimaru MJ, Tenkova T, Labruyère $\mathrm{J}$, Qin YQ, Ikonomidou $\mathrm{C}$, et al: Apoptosis in the in vivo mammalian forebrain. Neurobiol Dis 2001;8:359-379.

13 Miller MW, al-Ghoul WM: Numbers of neurons in the developing principal sensory nucleus of the trigeminal nerve: Enhanced survival of early-generated neurons over late-generated neurons. J Comp Neurol 1993;330:491501.

14 Waite PM, Li L, Ashwell KW: Developmental and lesion induced cell death in the rat ventrobasal complex. Neuroreport 1992;3:485-488.

15 Spreafico R, Frassoni C, Arcelli P, Selvaggio M, De Biasi S: In situ labeling of apoptotic cell death in the cerebral cortex and thalamus of rats during development. J Comp Neurol 1995; 363:281-295.

16 Ferrer I, Serrano T, Soriano E: Naturally occurring cell death in the subicular complex and hippocampus in the rat during development. Neurosci Res 1990;8:60-66.

17 Namura S, Zhu J, Fink K, Endres M, Srinivasan A, Tomaselli KJ, et al: Activation and cleavage of caspase- 3 in apoptosis induced by experimental cerebral ischemia. $\mathbf{J}$ Neurosci 1998;18:3659-3668.

18 Hill A: Current concepts of hypoxic-ischemic cerebral injury in the term newborn. Pediatr Neurol 1991;7:317-325.

19 McDonald JV: The surgical management of severe open brain injuries with consideration of the long-term results. J Trauma 1980;20: $842-847$

20 Alexander GE, Crutcher MD: Functional architecture of basal ganglia circuits: Neural sub- strates of parallel processing. Trends Neurosci 1990;13:266-271.

21 Johnston MV, Trescher WH, Ishida A, Nakajima W: Novel treatments after experimental brain injury. Semin Neonatol 2000;5:75-86.

22 Johnston MV, Nakajima W, Hagberg H: Mechanisms of hypoxic neurodegeneration in the developing brain. Neuroscientist 2002;8:212220.

23 Menkes JH, Curran J: Clinical and MR correlates in children with extrapyramidal cerebral palsy. Am J Neuroradiol 1994; 15:451-457.

24 Salford LG, Siesjo BK: The influence of arterial hypoxia and unilateral carotid artery occlusion upon regional blood flow and metabolism in the rat brain. Acta Physiol Scand 1974;92:130 141.

25 Siesjo BK: Cell damage in the brain: A speculative synthesis. J Cereb Blood Flow Metab 1981; 1:155-185.

26 Rehncrona S: Brain acidosis. Ann Emerg Med 1985;14:770-776.

27 Siesjo BK, Folbergrova J, MacMillan V: The effect of hypercapnia upon intracellular $\mathrm{pH}$ in the brain, evaluated by the bicarbonate-carbonic acid method and from the creatine phosphokinase equilibrium. J Neurochem 1972;19: 2483-2495.

28 Folbergrova J, MacMillan V, Siesjo BK: The effect of moderate and marked hypercapnia upon the energy state and upon the cytoplasmic NADH-NAD ${ }^{+}$ratio of the rat brain. J Neurochem 1972;19:2497-2505.

29 Paljarvi L, Soderfeldt B, Kalimo H, Olsson Y, Siesjo BK: The brain in extreme respiratory acidosis. A light- and electron-microscopic study in the rat. Acta Neuropathol (Berl) 1982; 58:87-94.

30 Williams CE, Mallard C, William T, Gluckman PD: Pathophysiology of perinatal asphyxia. Perinatal Asphyxia 1993;20:305-325. 
31 Olney JW, Wozniak DF, Jevtovic-Todorovic V, Ikonomidou C: Glutamate signaling and the fetal alcohol syndrome. Ment Retard Dev Disabil Res Rev 2001;7:267-275.

32 Olney JW, Wozniak DF, Jevtovic-Todorovic $\mathrm{V}$, Farber NB, Bittigau $\mathrm{P}$, Ikonomidou $\mathrm{C}$ : Drug-induced apoptotic neurodegeneration in the developing brain. Brain Pathol 2002;12: 488-498.

33 Bulterys MG, Greenland D, Kraus JF: Chronic fetal hypoxia and sudden infant death syndrome: Interaction between maternal smoking and low hematocrit during pregnancy. Pediatrics 1990;86:535-540.

34 Nakanishi N, Axel R, Shneider NA: Alternative splicing generates functionally distinct $\mathrm{N}$ methyl- $D$-aspartate receptors. Proc Natl Acad Sci USA 1992;89:8552-8556.

35 Ishii T, Moriyoshi K, Sugihara H, Sakurada K, Kadotani H, Yokoi M, et al: Molecular characterization of the family of the N-methyl- $D$ aspartate receptor subunits. J Biol Chem 1993; 268:2836-2843.

36 Monyer H, Burnashev N, Laurie DJ, Sakmann B, Seeburg PH: Developmental and regional expression in the rat brain and functional properties of four NMDA receptors. Neuron 1994; 12:529-540.

37 Nishi M, Hinds H, Lu HP, Kawata M, Hayashi $\mathrm{Y}$ : Motoneuron-specific expression of NR3B, a novel NMDA-type glutamate receptor subunit that works in a dominant-negative manner. J Neurosci 2001;21:RC185.

38 Takahashi T, Feldmeyer D, Suzuki N, Onodera K, Cull-Candy SG, Sakimura K et al: Functional correlation of NMDA receptor $\varepsilon$ subunits expression with the properties of single-channel and synaptic currents in the developing cerebellum. J Neurosci 1996; 16:4376-4382.

39 Akazawa C, Shigemoto R, Bessho Y, Nakanishi S, Mizuno N: Differential expression of five Nmethyl- $D$-aspartate receptor subunit mRNAs in the cerebellum of developing and adult rats. J Comp Neurol 1994;347:150-160.

40 Watanabe M, Mishina M, Inoue Y: Distinct distributions of five NMDA receptor channel subunit mRNAs in the brainstem. J Comp Neurol 1994;343:520-531

41 Monaghan DT, Bridges RJ, Cotman CW: The excitatory amino acid receptors: Their classes, pharmacology and distinct properties in the function of the central nervous system. Annu Rev Pharmacol Toxicol 1989;29:365-402.

42 Mayer ML, Westbrook GL, Guthrie PB: Voltage-dependent block by $\mathrm{Mg}^{2+}$ of NMDA responses in spinal cord neurones. Nature 1984; 309:261-263.

43 Collingridge G: Synaptic plasticity. The role of NMDA receptors in learning and memory. Nature 1987;330:604-605.

44 Ikonomidou C, Bosch F, Miksa M, Bittigau P, Vockler J, Dikranian K, et al: Blockade of NMDA receptors and apoptotic neurodegeneration in the developing brain. Science 1999; 283:70-74.

45 Portera Cailliau C, Price DL, Martin LJ: Excitotoxic neuronal death in the immature brain is an apoptosis-necrosis morphological continuum. J Comp Neurol 1997;378:70-87.
46 Crair MC, Malenka RC: A critical period for long-term potentiation at thalamocortical synapses. Nature 1995;375:325-328.

47 Feldman DE, Nicoll RA, Malenka RC, Isaac JT: Long-term depression at thalamocortical synapses in developing rat somatosensory cortex. Neuron 1998;21:347-357.

48 Ramoa AS, McCormick DA: Enhanced activation of NMDA receptor responses at the immature retinogeniculate synapse. J Neurosci 1994; 14:2098-2105.

49 McBain CJ, DiChiara TJ, Kauer JA: Activation of metabotropic glutamate receptors differentially affects two classes of hippocampal interneurons and potentiates excitatory synaptic transmission. J Neurosci 1994;14:44334445.

50 Scheetz AJ, Constantine-Paton M: Modulation of NMDA receptor function: Implications for vertebrate neural development. FASEB J 1994; 8:745-752.

51 Aamodt SM, Constantine-Paton M: The role of neural activity in synaptic development and its implications for adult brain function. Adv Neurol 1999;79:133-144.

52 Bear MF, Cooper LN, Ebner FF: A physiological basis for a theory of synapse modification. Science 1987;237:42-48.

53 Feldman DE, Nicoll RA, Malenka RC: Synaptic plasticity at thalamocortical synapses in developing rat somatosensory cortex: LTP, LTD, and silent synapses. J Neurobiol 1999;41:92101.

54 Piggott MA, Perry EK, Perry RH, Court JA: $\left[{ }^{3} \mathrm{H}\right] \mathrm{MK}-801$ binding to the NMDA receptor complex, and its modulation in human frontal cortex during development and aging. Brain Res 1992;588:277-286.

55 Slater P, McConnell SE, D'Souza SW, Barson AJ: Postnatal changes in N-methyl- $D$-aspartate receptor binding and stimulation by glutamate and glycine of $\left[{ }^{3} \mathrm{H}\right]-\mathrm{MK}-801$ binding in human temporal cortex. Br J Pharmacol 1993;108: 1143-1149.

56 Gould E, Cameron HA, McEwen BS: Blockade of NMDA receptors increases cell death and birth in the developing rat dentate gyrus. $\mathrm{J}$ Comp Neurol 1994;340:551-565.

57 Gould E, Cameron HA: Early NMDA receptor blockade impairs defensive behavior and increases cell proliferation in the dentate gyrus of developing rats. Behav Neurosci 1997;111:49_ 56.

58 Komuro H, Rakic P: Modulation of neuronal migration by NMDA receptors. Science 1993; 260:95-97.

59 Rakic P: Principles of neural cell migration. Experientia 1990;46:882-891.

60 Rakic P: Images in neuroscience. Brain development. VI. Radial migration and cortical evolution. Am J Psychiatry 1998;155:1150-1151.

61 McDonald JW, Johnston MV: Physiological and pathophysiological roles of excitatory amino acids during central nervous system development. Brain Res Rev 1990;15:41-70.

62 Brooks WJ, Petit TL, LeBoutillier JC, Lo R: Rapid alteration of synaptic number and postsynaptic thickening length by NMDA: An electron microscopic study in the occipital cortex of postnatal rats. Synapse 1991;8:41-48.
63 Brooks WJ, Petit TL, LeBoutillier JC: Effect of chronic administration of NMDA antagonists on synaptic development. Synapse 1997;26: 104-113.

64 Ohtake PJ, Simakajornboon N, Fehniger MD, Xue YD, Gozal D: N-methyl- $D$-aspartate receptor expression in the nucleus tractus solitarii and maturation of hypoxic ventilatory response in the rat. Am J Respir Crit Care Med 2000;162:1140-1147.

65 Poon CS, Zhou Z, Champagnat J: NMDA receptor activity in utero averts respiratory depression and anomalous long-term depression in newborn mice. J Neurosci 2000;20:RC73.

66 Kutsuwada T, Sakimura K, Manabe T, Takayama C, Katakura N, Kushiya E, et al: Impairment of suckling response, trigeminal neuronal pattern formation and hippocampal LTD in NMDA receptor epsilon 2 subunit mutant mice. Neuron 1996;16:333-344.

67 Rosenblum K, Berman DE, Hazvi S, Lamprecht R, Dudai Y: NMDA receptor and the tyrosine phosphorylation of its $2 \mathrm{~B}$ subunit in taste learning in the rat insular cortex. J Neurosci 1997; 17:5129-5135.

68 Khan AM, Curras MC, Dao J, Jamal FA, Turkowski CA, Goel RK, et al: Lateral hypothalamic NMDA receptor subunits NR2A and/or NR2B mediate eating: Immunochemical/behavioral evidence. Am J Physiol 1999;276: R880-R891.

69 Tang YP, Shimizu E, Dube GR, Rampon C, Kerchner GA, Zhuo M, et al: Genetic enhancement of learning and memory in mice. Nature 1999;401:63-69.

70 Wei F, Wang GD, Kerchner GA, Kim SJ, Xu $\mathrm{HM}$, Chen ZF, et al: Genetic enhancement of inflammatory pain by forebrain NR2B overexpression. Nat Neurosci 2001;4:164-169.

71 Cameron HA, McEwen BS, Gould E: Regulation of adult neurogenesis by excitatory input and NMDA receptor activation in the dentate gyrus. J Neurosci 1995; 15:4687-4692.

72 LoTurco JJ, Blanton MG, Kriegstein AR: Initial expression and endogenous activation of NMDA channels in early neocortical development. J Neurosci 1991;11:792-799.

73 Rossi DJ, Slater NT: The developmental onset of NMDA receptor-channel activity during neuronal migration. Neuropharmacology 1993;32:1239-1248.

74 Behar TN, Scott CA, Greene CL, Wen X, Smith SV, Maric D, et al: Glutamate acting at NMDA receptors stimulates embryonic cortical neuronal migration. J Neurosci 1999;19: 4449-4461.

75 Hirai K, Yoshioka H, Kihara M, Hasegawa K, Sakamoto T, Sawada T, et al: Inhibiting neuronal migration by blocking NMDA receptors in the embryonic rat cerebral cortex: A tissue culture study. Brain Res Dev Brain Res 1999; 114:63-67.

76 Contestabile A: Roles of NMDA receptor activity and nitric oxide production in brain development. Brain Res Brain Res Rev 2000;32: 476-509.

77 Brooks WJ, Weeks AC, Leboutillier JC, Petit TL: Altered NMDA sensitivity and learning following chronic developmental NMDA antagonism. Physiol Behav 1997;62:955-962. 
78 Wilson RI, Yanovsky J, Godecke A, Stevens DR, Schrader J, Haas HL: Endothelial nitric oxide synthase and LTP. Nature 1997;386: 338.

79 Daniel H, Levenes C, Crepel F: Cellular mechanisms of cerebellar LTD. Trends Neurosci 1998;21:401-407.

80 Paneth N, Kiely JL, Wallenstein S, Marcus M, Pakter J, Susser M: Newborn intensive care and neonatal mortality in low-birth-weight infants: A population study. N Engl J Med 1982; 307:149-155.

81 Sarnat HB, Sarnat MS: Neonatal encephalopathy following fetal distress. A clinical and electroencephalographic study. Arch Neurol 1976; 33:696-705.

82 Levene MI, Sands C, Grindulis H, Moore JR: Comparison of two methods of predicting outcome in perinatal asphyxia. Lancet 1986;i:6769.

83 Tenneti L, Lipton SA: Involvement of activated caspase-3-like proteases in N-methyl- $D$ aspartate-induced apoptosis in cerebrocortical neurons. J Neurochem 2000;74:134-142.

84 Johnston MV, Trescher WH, Ishida A, Nakajima W: Neurobiology of hypoxic-ischemic injury in the developing brain. Pediatr Res 2001; 49:735-741.

85 Machaalani R, Waters KA: Correlations between brainstem NMDA receptor changes and active neuronal cell death after intermittent hypercapnic hypoxia in the developing piglet. Brain Res 2003;975:141-148.

86 Guerguerian AM, Brambrink AM, Traystman RJ, Huganir RL, Martin LJ: Altered expression and phosphorylation of $\mathrm{N}$-methyl- $D$-aspartate receptors in piglet striatum after hypoxia-ischemia. Brain Res Mol Brain Res 2002;104:6680.

87 Raymond LA, Tingley WG, Blackstone CD, Roche KW, Huganir RL: Glutamate receptor modulation by protein phosphorylation. J Physiol 1994;88:181-192.

88 Swope SL, Moss SJ, Raymond LA, Huganir RL: Regulation of ligand-gated ion channels by protein phosphorylation. Adv Second Messenger Phosphoprotein Res 1999;33:49-78.

89 Tingley WG, Roche KW, Thompson AK, Huganir RL: Regulation of NMDA receptor phosphorylation by alternative splicing of the C-terminal domain. Nature 1993;364:70-73.

90 Tingley WG, Ehlers MD, Kameyama K, Doherty C, Ptak JB, Riley CT, et al: Characterization of protein kinase $\mathrm{A}$ and protein kinase $\mathrm{C}$ phosphorylation of the $\mathrm{N}$-methyl- $D$-aspartate receptor NR1 subunit using phosphorylation site-specific antibodies. J Biol Chem 1997;272 5157-5166.

91 Kim WT, Kuo MF, Mishra OP, DelivoriaPapadopoulos M: Distribution and expression of the subunits of $\mathrm{N}$-methyl- $D$-aspartate receptors: NR1, NR2A and NR2B in hypoxic newborn piglet brains. Brain Res 1998;799:49-54.

92 Mishra OP, Delivoria-Papadopoulos M: NMDA receptor modification in the fetal guinea pig brain during hypoxia. Neurochem Res 1992; 17:1211-1216
93 Mishra OP, Delivoria-Papadopoulos M: Modification of modulatory sites of NMDA receptor in the fetal guinea pig brain during development. Neurochem Res 1992;17:1223-1228.

94 Graham EM, Apostolou M, Mishra OP, Delivoria-Papadopoulos $\mathrm{M}$ : Modification of the $\mathrm{N}$-methyl- $D$-aspartate receptor in the brain of newborn piglets following hyperventilation induced ischemia. Neurosci Lett 1996;218: 29-32.

95 Fritz KI, Mishra OP, Delivoria-Papadopoulos $\mathrm{M}: \mathrm{Mg}^{2+}$-dependent modification of the $\mathrm{N}$-methyl- $D$-aspartate receptor following graded hypoxia in the cerebral cortex of newborn piglets. Neuroscience 1999;92:685-692.

96 Fritz KI, Groenendaal F, McGowan JE, Mishra OP, Delivoria-Papadopoulos M: Effect of cerebral hypoxia on NMDA receptor binding characteristics after treatment with 3-(2carboxypiperazin-4-yl)propyl-1-phosphonic acid in newborn piglets. Brain Res 1996;729: $66-74$

97 Fritz KI, Zanelli S, Mishra OP, DelivoriaPapadopoulos M: Effect of graded hypoxia on the high-affinity CPP binding site of the NMDA receptor in the cerebral cortex of newborn piglets. Brain Res 2001;891:266273.

98 Fritz KI, Zubrow AB, Mishra OP, DelivoriaPapadopoulos M: NMDA receptor modification during graded hypoxia in the cerebral cortex of newborn piglets. Biol Neonate 2002; 82:46-52.

99 Zanelli SA, Ashraf QM, Mishra OP: Nitration is a mechanism of regulation of the NMDA receptor function during hypoxia. Neuroscience 2002;112:869-877.

100 Waters KA, Tinworth KD: Depression of ventilatory responses after daily, cyclic hypercapnic hypoxia in piglets. J Appl Physiol 2001;90:1065-1073.

101 Cai Z, Rhodes PG: Intrauterine hypoxia-ischemia alters expression of the NMDA receptor in the young rat brain. Neurochem Res 2001; 26:487-495.

102 Gurd JW, Bissoon N, Beesley PW, Nakazawa T, Yamamoto T, Vannucci SJ: Differential effects of hypoxia-ischemia on subunit expression and tyrosine phosphorylation of the NMDA receptor in 7- and 21-day-old rats. J Neurochem 2002;82:848-856.

103 Aramakis VB, Hsieh CY, Leslie FM, Metherate R: A critical period for nicotine-induced disruption of synaptic development in rat auditory cortex. J Neurosci 2000;20:61066116.

104 Hsieh CY, Leslie FM, Metherate R: Nicotine exposure during a postnatal critical period alters NR2A and NR2B mRNA expression in rat auditory forebrain. Brain Res Dev Brain Res 2002;133:19-25.

105 Kinney HC, Filiano JJ, Harper RM: The neuropathology of the sudden infant death syndrome. A review. J Neuropathol Exp Neurol 1992;51:115-126.

106 Machaalani R, Waters KA: NMDA receptor 1 expression in the brainstem of human infants and its relevance to the sudden infant death syndrome. J Neuropathol Exp Neurol 2003;62:1076-1085.
107 Finer NN, Robertson CM, Richards RT, Pinnell LE, Peters KL: Hypoxic-ischemic encephalopathy in term neonates: Perinatal factors and outcome. J Pediatr 1981;98:112117

108 Andersen DL, Tannenberg AE, Burke CJ, Dodd PR: Regional development of glutamate N-methyl- $D$-aspartate receptor sites in asphyxiated newborn infants. J Child Neurol 1998;13:149-157.

109 Shankaran S: The postnatal management of the asphyxiated term infant. Clin Perinatol 2002;29:675-692.

110 Nelson KB, Grether JK: Can magnesium sulfate reduce the risk of cerebral palsy in very low birthweight infants? Pediatrics 1995;95: 263-269.

111 Atkinson MW, Guinn D, Owen J, Hauth JC: Does magnesium sulfate affect the length of labor induction in women with pregnancyassociated hypertension? Am J Obstet Gynecol 1995;173:1219-1222.

112 Levene M, Blennow M, Whitelaw A, Hanko E, Fellman V, Hartley R: Acute effects of two different doses of magnesium sulphate in infants with birth asphyxia. Arch Dis Child Fetal Neonatal Ed 1995;73:F174-F177.

113 Greenwood K, Cox P, Mehmet H, Penrice J, Amess PN, Cady EB, et al: Magnesium sulfate treatment after transient hypoxia-ischemia in the newborn piglet does not protect against cerebral damage. Pediatr Res 2000;48:346350 .

114 Penrice J, Amess PN, Punwani S, Wylezinska M, Tyszczuk L, D'Souza P, et al: Magnesium sulfate after transient hypoxia-ischemia fails to prevent delayed cerebral energy failure in the newborn piglet. Pediatr Res 1997;41:443447.

115 Hoffman DJ, Marro PJ, McGowan JE, Mishra OP, Delivoria-Papadopoulos M: Protective effect of $\mathrm{MgSO}_{4}$ infusion on NMDA receptor binding characteristics during cerebral cortical hypoxia in the newborn piglet. Brain Res 1994;644:144-149.

116 Ravishankar S, Ashraf QM, Fritz K, Mishra OP, Delivoria-Papadopoulos M: Expression of Bax and Bcl-2 proteins during hypoxia in cerebral cortical neuronal nuclei of newborn piglets: Effect of administration of magnesium sulfate. Brain Res 2001;901:23-29.

117 Levene M: Role of excitatory amino acid antagonists in the management of birth asphyxia. Biol Neonate 1992;62:248-251.

118 Hattori H, Morin AM, Schwartz PH, Fujikawa DG, Wasterlain CG: Posthypoxic treatment with MK-801 reduces hypoxic-ischemic damage in the neonatal rat. Neurology 1989 ; 39:713-718

119 Jevtovic-Todorovic V, Hartman RE, Izumi Y, Benshoff ND, Dikranian K, Zorumski CF et al: Early exposure to common anesthetic agents causes widespread neurodegeneration in the developing rat brain and persistent learning deficits. J Neurosci 2003;23:876882.

120 Reisberg B, Doody R, Stoffler A, Schmitt F, Ferris S, Mobius HJ, et al: Memantine in moderate-to-severe Alzheimer's disease. N Engl J Med 2003;348:1333-1341. 